\title{
Structural and Spectral characterization, Topological study and activity prediction of antiviral (E)-5-(diethylamino)-2-((3,5- dinitrophenylimino)methyl)phenol against SARS-CoV-2 Main Protease
}

asli esme ( $\square$ asliesme@gmail.com )

Kocaeli Universitesi

Research Article

Keywords: Schiff base, Hirshfeld surface analysis, Molecular docking, Topology calculations, SARS-CoV-2 Main Protease

Posted Date: October 22nd, 2021

DOI: https://doi.org/10.21203/rs.3.rs-985601/v1

License: () (1) This work is licensed under a Creative Commons Attribution 4.0 International License. Read Full License 


\section{Abstract}

The (E)-5-(diethylamino)-2-((3,5-dinitrophenylimino)methyl)phenol was deliberated by Ultraviolet-Visible (UV-Vis) and Fourier Transform Infrared (FT-IR) spectroscopy techniques. Hirshfeld surface analysis was performed to analyze the contribution of intermolecular contacts in crystal structure of the studied Schiff base ligand. The plots of the highest occupied molecular orbital (HOMO), the lowest unoccupied molecular orbital (LUMO), and the electrostatic potential (ESP) were used to research the nucleophilic and electrophilic attack sites for the Schiff base ligand. According to the ESP analysis, the electrophilic reactivity was mainly found in nitro and hydroxy groups attached to phenyl rings, while the nucleophilic attack was more concentrated on hydrogen atoms. Major contributions from molecular orbitals to the electronic transitions computed according to the timedependent DFT (TD-DFT) method were investigated using chloroform as a solvent. The topological parameters; electron density, Laplacian of electron density, kinetic energy, electron potential energy density, total electron energy density, ellipticity, hydrogen bond energy at the bond critical points have been evaluated. The compound was docked into the severe acute respiratory syndrome coronavirus 2, including a 3-chymotrypsin-like protease receptor's active site with the PDB ID 6LU7. The Schiff base ligand exhibited a good activity against coronavirus main protease receptor with $6 \mathrm{LU7}$ protein as compared with Chloroquine, Favipiravir, and Remdesivir with $-4.68 \mathrm{kcal} / \mathrm{mol}$ value of the binding energy.

\section{Introduction}

Schiff bases, an organic system characterized by an azomethine or imine functional (-HC=N-) group, can contain reversible intramolecular proton transfer from an oxygen atom to a neighboring nitrogen atom. Schiff bases can be found in two tautomeric structures as enol $(\mathrm{O}-\mathrm{H} \cdots \mathrm{N})$ and keto $(\mathrm{N}-\mathrm{H} \cdots \mathrm{O})$ forms ${ }^{[1]}$. A Schiff base has reported possessing good electronic and non-linear optical properties ensue from delocalized $\pi$ - and non-bonding electrons that move along molecule ${ }^{[2,3]}$. If the donor and acceptor groups are increases, non-linear optical properties (the polarizability and first-order hyperpolarizability) of a molecule increase ${ }^{[4]}$. The tautomeric forms of the Schiff base can be used as the anion sensors and design of different molecular electronic devices such as optical switches and optical memory devices ${ }^{[5]}$. The presence of the azomethine group in heterocyclic Schiff base derivatives has been shown to be critical for various biological activities such as antifungal[ $[6,7]$, antibacteria| $[8,9]$, antiproliferative ${ }^{[10]}$, anticoagulant ${ }^{[11]}$, anti-inflammatory ${ }^{[12]}$, and antiviral ${ }^{[13]}$ agents.

The (E)-5-(diethylamino)-2-((3,5-dinitrophenylimino)methyl)phenol (DNP) compound $\mathrm{C}_{23} \mathrm{H}_{24} \mathrm{~N}_{2} \mathrm{O}_{2}$ is synthesized and confirmed by single crystal X-ray diffraction studies ${ }^{[14]}$. To the best of our knowledge in literature, density functional theory (DFT) calculation of the title compound has not been reported. The investigated compound was examined its structure by infrared spectra (FT-IR) and ultraviolet-visible spectra (UV-Vis). The studies on DNP compound have been carried out DFT based computational study as the topological analysis of Atoms in Molecules (AIM) theory, nonlinear optical (NLO) properties, electronic absorption, vibrational spectroscopic properties, and electrostatic potential (ESP) analysis on molecular van der Waals (vdW) surface used to find the most reactive sites for the electrophilic and nucleophilic attack to support and confirm experimental records ${ }^{[14]}$. The calculations of UV-Vis. spectroscopic parameters (oscillator strengths, wavelengths, and excitation energies) of DNP were performed by the time-dependent density functional theory (TD-DFT) method, and the electronic transitions were established in chloroform solvent using GaussSum ${ }^{[15]}$. Finally, the study was complemented by molecular docking calculations of DNP compound against SARSCoV-2 protein, including a 3-chymotrypsin-like protease (PDB ID: 6LU7).

\section{Computational Details}

Gaussian 09 Rev. A 11.4 ${ }^{[16]}$ with DFT method using the three-parameter hybrid functional of Becke based on the correlation functional of Lee, Yang, and Parr (B3LYP) ${ }^{[17,18]}$ at 6-311++G(d,p) basis set and Gauss View Rev. 5.0.9 ${ }^{[19]}$ software programs were utilized to obtain the molecular geometry optimization of (E)-5-(diethylamino)-2-((3,5-dinitrophenylimino)methyl)phenol (DNP) compound and to visualize the calculation results, respectively. The vibrational frequencies computed at the DFT/B3LYP functional of the molecule were prepared with the assistance of the VEDA4 program ${ }^{[20]}$ using the PED - Potential Energy Distribution and compared with the experimental values ${ }^{[14]}$. Multiwfn software ${ }^{[21]}$ has been used to perform Atoms In Molecule 
(AIM) analysis, the Critical Bond Point (BCP), the reduced density gradient (RDG), electrostatic potential (ESP) on molecular van der Waals (vdW) surface for DNP.

\section{Results And Discussion Geometric structure}

The crystallographic data for the studied crystalline system in a noncentrosymmetric space group $\left(P 2{ }_{1} 2{ }_{1}{ }_{1}\right)$ and in an orthorhombic crystal system are $a=6.6367(2) \AA, b=8.1942(2) \AA$, and $c=30.9362(9) \AA^{[14]}$. For the geometry optimization of the title compound, the DFT/B3LYP level of theory with $6-311++G(d, p)$ basis set was used. The selected optimized geometrical parameters of (E)-5-(diethylamino)-2-((3,5-dinitrophenylimino)methyl)phenol (DNP) molecule are reported in Table 1 and the optimized molecular diagram with the numbering of atoms is presented in Figure 1.

As a result of intramolecular proton transfer, schiff bases can exist in two tautomeric structures as enol and keto forms in the solid state. The N2 - C7 and 01 - C1 bond distances that are descriptive for Schiff bases were 1.284(4) $\AA$ / 1.3012 $\AA$ and 1.346(3) $\AA$ / $1.3417 \AA$ for $\mathrm{X}$-ray ${ }^{[14]} / \mathrm{DFT} / \mathrm{B} 3 \mathrm{LYP}$ results, respectively. The bond distance between $\mathrm{N} 2$ and $\mathrm{C} 7$ is consistent with an $\mathrm{N}=\mathrm{C}$ double bond, while the $01-\mathrm{C} 1$ bond distance is consistent with the $\mathrm{O}-\mathrm{C}$ single band. The double $\mathrm{C}=\mathrm{N}$ bond and single $\mathrm{O}-\mathrm{C}$ bond lengths correspond well with those previously reported for the related compounds ${ }^{[22,23]}$. It is concluded on the basis of DFT results that the $\mathrm{H} 1$ atom is located on 01 atom, thus the DNP compound exists in enol form.

The torsion angle (C6-C7-N2-C8) observed as $-178.7(3)^{\circ}{ }^{0[14]}$ and calculated at $175.94^{\circ}$ is consistent with the corresponding distances in the related Schiff bases structures ${ }^{[24,25]}$. The dinitrophenylimino group is almost coplanar with the attached ring with C6-C7-N2-C8 torsion angle of $175.94^{\circ}$ for the DFT/B3LYP method.

This intramolecular hydrogen bond $01-\mathrm{H} 1 \bullet . \bullet \mathrm{N} 2$ with A $\bullet \bullet \mathrm{D}$ distance of $2.633(3) \AA$ and $\mathrm{A} \bullet \bullet \cdot \mathrm{H}-\mathrm{D}$ angle of $146.2(5)^{\mathrm{o}[14]}$ is characterized by distance of $2.6495 \AA$ and angle of $147.22^{\circ}$ using B3LYP/6-311++G(d,p) level of theory, being shorter than the sum of the Van der Waals radius of the $\mathrm{N}$ and $\mathrm{O}$ atoms $(3.07 \AA)^{[26]}$.

\section{Hirshfeld surface analysis}

Hirshfeld surface analysis with Hirshfeld surfaces and two-dimensional fingerprint plots generated with Crystal Explorer version 3.1 software $^{[27]}$ is a useful technique for determining intermolecular interactions in crystal structures. The red and blue spots on the normalized contact distance $\left(d_{\text {norm }}\right)$ surface given in Fig. 2 represent the contacts with distances shorter (in close contact) or longer (distinct contact) than the Van der Waals radii, respectively. The smaller red areas known to be hydrogen-acceptor regions in Fig. 2 is attributed to $\mathrm{O} \cdots \mathrm{H} / \mathrm{H} \cdots \mathrm{O}$ contacts, but representing $\mathrm{C}-\mathrm{H} \cdots \mathrm{O}$ (distance of $2.380 \AA$ ) hydrogen bonds between the $\mathrm{H} 13$ atom of the hydroxyl group and the 01 atom of the phenyl ring. The two-dimensional fingerprint plots providing information on the percentage contributions of the various interatomic contacts are shown in Fig. 3. The most important are $\mathrm{H} \cdots \mathrm{H}$ interactions, which contribute $35.6 \%$ to the total Hirshfeld surface, while the other contributions are from $0 \cdots \mathrm{H} / \mathrm{H} \cdots \mathrm{O}(35.8 \%)$ contacts. As a result, $\mathrm{H} \cdots \mathrm{H}$ and $\mathrm{O} \cdots \mathrm{H} / \mathrm{H} \cdots \mathrm{O}$ contacts accounted for more than $71.4 \%$ of the Hirshfeld surface, whereas the $\mathrm{H} \cdots \mathrm{C} / \mathrm{C} \cdots \mathrm{H}$ interaction only contributed to $9.1 \%$ of the surface.

\section{Vibrational Analysis}

The Fourier transform infrared (FT-IR) spectra of the functional groups present in the structure of DNP compound have been studied by workers ${ }^{[14]}$. For visual comparison, the observed ${ }^{[14]}$ FT-IR bands and calculated wavenumbers investigated with VEDA 4 program by considering PEDs of DNP are depicted in Table 2. Unscaled wavenumbers obtained at the DFT/B3LYP/6-311++GG(d,p) level of theory were scaled with a factor of 0.958 for wavenumbers greater than $1100 \mathrm{~cm}^{-1}$ and 0.983 for wavenumbers less than $1100 \mathrm{~cm}^{-1}$. The experimental and simulated DFT (B3LYP) FT-IR spectrum of the studied compound is given in Figure 4 .

\section{Hydroxy $(\mathrm{OH})$ vibrations}

Due to the strong intramolecular interactions between hydroxyl group and imine group in the compound, the $\mathrm{O}-\mathrm{H}$ stretching vibration mode under intramolecular hydrogen bonding is observed at the interval $3100-3450 \mathrm{~cm}^{-1}[28]$. The experimental ${ }^{[14]} \mathrm{FT}-\mathrm{IR}$ 
spectrum of DNP was presented the $\mathrm{O}-\mathrm{H}$ stretching peak at $3415 \mathrm{~cm}^{-1}$. In this study, the $\mathrm{O}-\mathrm{H}$ stretching vibration which broaden owing to the formation of strong intramolecular hydrogen bonding $\mathrm{O}-\mathrm{H} \cdots \mathrm{N}$ in the DNP was computed as $3127 \mathrm{~cm}^{-1}$ with a PED contribution of $98 \%$. The theoretically calculated values at $1517 \mathrm{~cm}^{-1}(27 \%)$ and $812,808 \mathrm{~cm}^{-1}(40 \%, 34 \%)$ are assigned to $\mathrm{OH}$ group in-plane $\sigma(\mathrm{HOC})$ and out-of-plane $\tau(\mathrm{HOCC})$ modes, respectively, in agreement with the literature data ${ }^{[29,30]}$.

\section{Methyl $\left(\mathrm{CH}_{3}\right)$ and Methylene $\left(\mathrm{CH}_{2}\right)$ groups vibrations}

The asymmetric stretching vibrations of the aliphatic $\mathrm{CH}_{3} / \mathrm{CH}_{2}$ groups are typically observed in the interval $2980 \mathrm{~cm}^{-1} / 3000-$ 2900 , while the symmetric stretching vibrations are observed at the interval of $\sim 2870 \mathrm{~cm}^{-1} / 2900-2800 \mathrm{~cm}^{-1}$, respectively ${ }^{[31,32]}$. The asymmetric $v_{\text {as }}\left(\mathrm{CH}_{3}\right)$ stretching vibrations (mode nos: 8-11) are occur with the rang 2984-2966 $\mathrm{cm}^{-1}$ with PED contribution of $73-85 \%$, the computed symmetric $\mathrm{v}_{\mathrm{s}}\left(\mathrm{CH}_{3}\right)$ wavenumbers are at 17 and 18 having wavenumbers at 2908 and $2905 \mathrm{~cm}^{-1}$ with PED contribution of $\sim 84 \%$. The $\mathrm{CH}_{2}$ vibrational modes separated as asymmetric and symmetric were calculated at $2953,2944 \mathrm{~cm}^{-1}$ $\left(85 \%, 89 \%\right.$ PED) and $2919,2915 \mathrm{~cm}^{-1}\left(90 \%, 98 \%\right.$ PED) for DNP, respectively, and in good agreement with the literature ${ }^{[33]}$. The bending vibrations of these $\mathrm{CH}_{2}$ and $\mathrm{CH}_{3}$ groups were found to be at 1464,1448 and $1442,1435,1433,1427,1425 \mathrm{~cm}^{-1}$ while twisting modes were observed at $1284(36 \%)$, respectively.

\section{Nitro $\left(\mathrm{NO}_{2}\right)$ group vibrations}

The asymmetric $\left(\mathrm{vas}_{\text {as }}\left(\mathrm{NO}_{2}\right)\right)$ and symmetric $\left(\mathrm{v}_{\mathrm{s}}\left(\mathrm{NO}_{2}\right)\right)$ stretching vibrations of the aromatic nitro $\left(\mathrm{NO}_{2}\right)$ compounds ${ }^{[34,35]}$ have strong absorptions at $1485-1570 \mathrm{~cm}^{-1}$ and $1320-1370 \mathrm{~cm}^{-1}$, respectively. In our study, the $\mathrm{NO}_{2}$ asymmetric and asymmetric stretching modes are observed at $1532,1512 \mathrm{~cm}^{-1}$ and $1319,1303 \mathrm{~cm}^{-1[14]}$ and these values are calculated at $1524,1520 \mathrm{~cm}^{-1}$ with PED contribution of $49 \%, 47 \%$ and $1317,1310 \mathrm{~cm}^{-1}$ (B3LYP) with PED contributions of $65 \%, 79 \%$.

\section{Carbon - Nitrogen Vibrations}

The most characteristic region of $1500-1700 \mathrm{~cm}^{-1}$ can be used to describe the $\mathrm{N}=\mathrm{C}$ stretching vibration of the Schiff base derivatives ${ }^{[28]}$. The calculated value for $\mathrm{v}(\mathrm{C}=\mathrm{N})$ is predicted at $1558 \mathrm{~cm}^{-1}$ with $\mathrm{PED}$ contribution of $30 \%$, while the azomethine $\mathrm{N}=\mathrm{C}$ stretching vibration is observed a strong band (Fig. 4) at $1585 \mathrm{~cm}^{-1}$ in FT-IR spectrum ${ }^{[14]}$. The N-C stretching vibrational for all amine compounds ${ }^{[36]}$ exhibit in the region $1000-1350 \mathrm{~cm}^{-1}$. The observed stretching band at $1338 \mathrm{~cm}^{-1}$ can be assigned to N1C3 stretching mode for DNP ${ }^{[14]}$ and this band was calculated at $1392 \mathrm{~cm}^{-1}$ (12\% PED) using DFT/B3LYP6-311++G(d,p) level of theory. The N-C stretching vibration for 2-[(4-propylphenylimino)methyl]-4-nitrophenol molecule has been assigned at $1178 \mathrm{~cm}^{-1}$ using the B3LYP/6-31G(d) method by Ağar et. al. ${ }^{[37]}$. In this study, the N2-C8 stretching vibration was calculated at $1183,974 \mathrm{~cm}^{-1}$ for B3LYP level of theory with the $15 \%, 16 \%$ contributions of PED.

\section{Carbon-Carbon Vibrations}

The aromatic $C=C$ stretching vibration was observed at the $1637 \mathrm{~cm}^{-1}$ experimentally ${ }^{[14]}$, and calculated as $1608 \mathrm{~cm}^{-1}$ (47\% PED), which agree well with the literature data. The benzene ring and its derivatives were specified in the range of $1650-1450 \mathrm{~cm}^{-1}$ in terms of the $\mathrm{C}-\mathrm{C}$ stretching modes ${ }^{[38,39]}$. The $\mathrm{C}-\mathrm{C}$ stretching vibrations computed at the DFT/B3LYP/6-311++G(d,p) level of theory were obtained in the interval 1608 (47\%) / $1324(42 \%) \mathrm{cm}^{-1}$ (ring A) and $1593(29 \%) / 984(13 \%) \mathrm{cm}^{-1}$ (ringB). The reason why these frequencies are slightly different between the rings may be that there is a functional group attached to the ring.

\section{Frontier molecular orbitals analysis}

The frontier molecular orbitals (FMOs) which have the advantage of analyzing the chemical properties and kinetic stability of the molecule are illustrated in Fig. 5. The lowest unoccupied molecular orbital energy $E_{\text {LUMO }}$ measures the electron-accepting character of a compound, while the highest occupied molecular orbital energy $E_{\mathrm{HOMO}}$ assesses its electron-donating character. The HOMO orbitals are mainly located on the whole molecule except $\mathrm{NO}_{2}$ groups attached to the phenyl ring, while LUMO orbitals are localized mainly on phenyl ring carrying both $\mathrm{NO}_{2}$ groups. 
The energy gap $\left(\Delta E=E_{\mathrm{LUMO}}-E_{\mathrm{HOMO}}\right)$, lonization potential $\left(\mathrm{I}=-E_{\mathrm{HOMO}}\right)$, Electron affinity $\left(\mathrm{A}=-E_{\mathrm{LUMO}}\right)$, Chemical hardness $(\eta=(\mathrm{I}-$ A)/2), Chemical softness $(\sigma=1 / \eta)$, chemical potential $(\mu=-(I+A) / 2)$, electrophilicity index $\left(\omega=\mu^{2} / 2 \eta\right)$ for DNP have been calculated at DFT/B3LYP/6-311++G(d,p) level of theory and tabulated in Table 3. The energy gap of LUMO - HOMO explains the ultimate charge transfer interaction within the molecule DNP was found to be $2.7317 \mathrm{eV}$. The high value of the chemical hardness (the low value of the softness) related to the energy gap shows the stability of the molecule. The chemical hardness ( $\eta$ ) and softness $(\sigma)$ obtained using the HOMO and LUMO energies were predicted as $1.3659 \mathrm{eV}^{2}$ and $0.7321 \mathrm{eV}^{-1}$, respectively. The calculated values of $\Delta E$ and $\eta$ for DNP are smaller than those of ( $E$ )-2-[(2-Chlorophenyl) iminomethyl]-4-trifluoromethoxyphenol $(\Delta \mathrm{E}=4.081 \mathrm{eV}$ and $\eta=2.040 \mathrm{eV})$ as a comparison to the corresponding Schiff base compound in the literature ${ }^{[40]}$. The energy gap $(\Delta E)$ and the global hardness parameters $(\eta)$ of DNP show that the studied Schiff base is not chemically hard, implying that it is highly polarizable and chemically reactive. Besides, the lower electrophilicity index value of $0.6830 \mathrm{eV}$ suggests that the title compound has biological activity ${ }^{[41]}$.

\section{Electrostatic potential analysis}

The electrostatic potential (ESP) on molecular van der Waals (vdW) surface is a major parameter for describing regions responsible for hydrogen bonding interactions as well as potential electrophilic and nucleophilic sites in a molecule ${ }^{[42,43]}$. In the 3D ESP plot van der Waals (vdW) surface along with the surface minima and maxima is shown in Fig. 6a, the color scale of the map ranges between $-22.00 \mathrm{kcal} / \mathrm{mol}$ and $+22.00 \mathrm{kcal} / \mathrm{mol}$. it can be seen that the global surface minimum value $(-31.66$ $\mathrm{kcal} / \mathrm{mol}$ ) was found at the oxygen atom of the $\mathrm{NO}_{2}$ group, while the global surface maximum $(+28.34 \mathrm{kcal} / \mathrm{mol})$ is about the hydrogen atoms of the $\mathrm{CH}_{3}$ group. Additionally, the negative regions with the blue color indicate sites for electrophilic reactivity are mainly located on the $\mathrm{NO}_{2}$ and $\mathrm{OH}$ groups attached to phenyl rings, whereas the positive region is more concentrated on hydrogen atoms indicating a possible site for nucleophilic attack. The surface area in different ESP ranges is represented in Fig. $6 \mathrm{~b}$. The vdW surface area of the $\mathrm{NO}_{2}$ and $\mathrm{OH}$ groups' moiety is $114.30 \AA^{2}$, which occupies $29.7 \%$ of the overall surface.

\section{Ultraviolet-Visible Studies}

The percentage contributions of molecular orbitals to formation of the bands were obtained by using Gaussum program 3.0. ${ }^{[15]}$. For enol form of the studied compound, wavelength $(\lambda, \mathrm{nm})$, oscillator strength $(f$, a.u), major contributions of calculated transitions are given in Table 4. Inset of Fig. 7 shows the absorption band at $413 \mathrm{~nm}$ (in chloroform) is attributed to the $n \rightarrow \pi^{*}$ electronic transition ${ }^{[14]}$. Considering the TD-DFT calculations, it can be said that the theoretical electronic absorption spectrum of the Schiff base DNP ligand at $379.34 \mathrm{~nm}$ arises from HOMO $\rightarrow$ LUMO (97\%) transitions.

\section{Topology calculations}

Atoms in Molecules (AIM) is an effective and widely used tool for determining intramolecular and intermolecular hydrogen bonding ${ }^{[44]}$. According to the topological analysis of Atoms in Molecules (AIM) theory, to assign an interaction between two primary atoms, the intramolecular $\mathrm{O}-\mathrm{H} \bullet \bullet \mathrm{N}$ links have investigated to analyze characteristics of the Critical Bond Point (BCP). The calculated electron density $\left(\rho_{\mathrm{BCP}}\right)$, Laplacian of electron density $\left(\nabla^{2} \rho_{\mathrm{BCP}}\right)$, Lagrangian kinetic energy $\left(\mathrm{G}_{\mathrm{BCP}}\right)$, electron potential energy density $\left(\mathrm{V}_{\mathrm{BCP}}\right)$, total electron energy density $\left(\mathrm{H}_{\mathrm{BCP}}\right)$, ellipticity $\left(\varepsilon_{\mathrm{BCP}}\right)$, hydrogen bond energy $\left(\mathrm{E}_{\mathrm{HB}}\right)$ at hydrogen bonding $\mathrm{BCPs}$ are represented in Table 5. Hydrogen bonds can be classified as follows ${ }^{[45]}$, weak hydrogen bonds $\left(\mathrm{E}_{\mathrm{HB}}<12.0 \mathrm{kcal} / \mathrm{mol}\right) ; \nabla^{2}\left(\mathrm{r}_{\mathrm{BCP}}\right)$ $>0$ and $\mathrm{G}\left(\mathrm{r}_{\mathrm{BCP}}\right)+\mathrm{V}\left(\mathrm{r}_{\mathrm{BCP}}\right)>0$; medium hydrogen bonds $\left(12.0<\mathrm{E}_{\mathrm{HB}}<24.0 \mathrm{kcal} / \mathrm{mol}\right) ; \nabla^{2}\left(\mathrm{r}_{\mathrm{BCP}}\right)>0$ and $\mathrm{G}\left(\mathrm{r}_{\mathrm{BCP}}\right)+\mathrm{V}\left(\mathrm{r}_{\mathrm{BCP}}\right)<0$; strong hydrogen bonds $\left(\mathrm{E}_{\mathrm{HB}}>24.0 \mathrm{kcal} / \mathrm{mol}\right) ; \nabla^{2} \rho\left(\mathrm{r}_{\mathrm{BCP}}\right)<0$ and $\mathrm{G}\left(\mathrm{r}_{\mathrm{BCP}}\right)+\mathrm{V}\left(\mathrm{r}_{\mathrm{BCP}}\right)<0$ where $\mathrm{G}\left(\mathrm{r}_{\mathrm{BCP}}\right)+\mathrm{V}\left(\mathrm{r}_{\mathrm{BCP}}\right)$ is also known as total electronic energy density, $\mathrm{H}\left(\mathrm{r}_{\mathrm{BCP}}\right)$. It can be seen in Fig. 8 that 63 index corresponds to the bond critical point $(\mathrm{BCP})$ of the intramolecular hydrogen bond $01-\mathrm{H} 1 \cdots \mathrm{N} 2$. The $\rho(\mathrm{r})$ at the $63 \mathrm{BCP}$ moiety for hydrogen bond is close to 0.04 a.u and $\nabla^{2} \rho_{\mathrm{BCP}}$ value is in the range of $0.02-0.15 \mathrm{a} . u$, which is the maximum threshold value ensuring the formation of hydrogen bond ${ }^{[46]}$. The $\mathrm{V}_{\mathrm{BCP}}$ at this $\mathrm{BCP}$ is found to be -0.041927 a.u, therefore the hydrogen bond energy $\mathrm{E}_{\mathrm{HB}}=0.5 \mathrm{~V}_{\mathrm{BCP}}$ could be evaluated as $E_{\mathrm{HB}}=$ $-13.154907 \mathrm{kcal} / \mathrm{mol}$. The hydrogen bond energy $E_{\mathrm{HB}}$ is $-13.154907 \mathrm{kcal} / \mathrm{mol}, \nabla^{2}\left(\mathrm{r}_{\mathrm{BCP}}\right)>0$ and $\mathrm{G}\left(\mathrm{r}_{\mathrm{BCP}}\right)+\mathrm{V}\left(\mathrm{r}_{\mathrm{BCP}}\right)<0$ indicating that the hydrogen bond is medium hydrogen bond. 
The reduced density gradient (RDG) derived from electron density as a dimensionless quantity was developed by Johnson et al. [47].

$$
R D G(r)=\frac{1}{2\left(3 \pi^{2}\right)^{1 / 3}} \frac{\left|\nabla^{2} \rho(r)\right|}{\rho(r)^{4 / 3}}
$$

where $\rho(r)$ and $\nabla \rho(r)$ is the electron density and the gradient of $\rho(r)$ at the point $r$, respectively. RDG is a helpful approach to explore non-covalent interactions $(\mathrm{NCl})$ in real space, such as both intra- and intermolecular weak interactions (like hydrogen bonds) and is represented in Fig. 9. The graphical representation of $\rho(r)$ versus $\operatorname{sign}\left(\lambda_{2}\right) \rho$ are used to explain the repulsive $\left(\operatorname{sign}\left(\lambda_{2}\right) \rho>0\right)$, attractive $\left(\operatorname{sign}\left(\lambda_{2}\right) \rho<0\right)$ and Van der Waals $\left(\operatorname{sign}\left(\lambda_{2}\right) \rho \approx 0\right)$ interactions. As can be seen in Fig. 9 (2D scatter plot), the hydrogen bonding interactions between the nitrogen and the hydrogen atoms were detected between -0.020 and -0.005 a.u. The 3D RDG isosurface densities of DNP in Fig. 9 show the non-covalent interactions of DNP including hydrogen bonds, van der Waals interactions and steric effects. The elliptical plate between $\mathrm{O}-\mathrm{H}$ and imine $\mathrm{N}$ atoms shows the more blue region, which means the attractive interactions. As a result of this, we can conclude that there is a strong hydrogen bond.

\section{Nonlinear Optical Properties}

The Nonlinear Optical (NLO) activity values of dipole moment $\mu$ (D), mean polarizabity $\langle a\rangle$ (in a.u. and esu), the anisotropic of the polarizability $\langle\Delta a\rangle$ (in a.u.) and the mean first-order hyperpolarizability $\beta$ (in a.u. and esu) are calculated using the DFT/B3LYP/6$311++G(d, p)$ level of theory. The components of dipole moment, mean polarizabity, the anisotropic of the polarizability, and the mean first-order hyperpolarizability of the title compound can be seen in Table 6 . The $\beta$ for DNP calculated at the DFT/B3LYP/6$311++G(d, p)$ level of theory is $85.9094 \times 10^{-30}$ esu that is approximately 110 times greater than the magnitude of urea (for urea $\beta$ is found to be $0.7803 \cdot 10^{-30} \mathrm{esu}^{[48]}$ obtained at the same method). The large value of $\beta$ calculated by the DFT/B3LYP method shows that the title compound has useful NLO properties.

\section{Molecular docking analysis}

The PDB file of DNP was generated from the optimized molecular structure of the title compound. The three-dimensional (3D) structure of severe acute respiratory syndrome coronavirus 2 (SARS-CoV-2) virus, including a 3-chymotrypsin-like protease (3CL ${ }^{\text {pro }}$ ) was downloaded from RCSB PDB database (PDB ID: 6LU7) available at https://www.rcsb.org/structure/6LU7 ${ }^{[49]}$. The behavior of the studied compound into the functional sites of receptor 6 LU7 protein was conducted by the Autodock $4.2^{[50]}$. Discovery Studio Visualizer from Biovia was used to evaluate the $2 \mathrm{D}$ structure and the nature of interactions between ligand and $3 \mathrm{CL}^{\text {pro }}$ (6LU7) protein $^{[51]}$. Theses enzymes were prepared for docking using the PyMOL molecular viewer (VMD) ${ }^{[52]}$.

The docking results including docking binding energies $(\mathrm{kcal} / \mathrm{mol})$, inhibition constants $(\mu \mathrm{m})$, intermolecular energies $(\mathrm{kcal} / \mathrm{mol})$, and amino acid residues that have $\mathrm{H}$-bond interactions with the ligand were listed in Table 7. As can be seen Fig. 10, DNP exhibited up to $\mathrm{NO}_{2}$ and $\mathrm{OH}$ conventional hydrogen bond interactions with LYS5 (5.6 $\left.\mathrm{A}\right)$, ARG4 (2.1 $\AA$ ), and PHE3 (3.3 $\left.\mathrm{A}\right)$ active sites, respectively. The following is the increasing order of binding energies DNP $(-4.68 \mathrm{kcal} / \mathrm{mol})<\mathrm{Chloroquine}(-4.62 \mathrm{kcal} / \mathrm{mol})<$ Favipiravir $(-3.88 \mathrm{kcal} / \mathrm{mol})<$ Remdesivir $(-3.45 \mathrm{kcal} / \mathrm{mol})$. According to studied results, the DNP compound has a better affinity for the COVID 19 main protease receptor compared to Chloroquine, Favipiravir, and Remdesivir.

\section{Conclusion}

The (E)-5-(diethylamino)-2-((3,5-dinitrophenylimino)methyl)phenol (DNP) was characterized by the Ultraviolet-Visible and Fourier Transform Infrared spectral studies. The $\mathrm{H} \cdots \mathrm{H}$ contacts have a major contribution for the studied ligand of $35.6 \%$ to the total Hirshfeld surface. The vibrational assignments calculated at DFT/B3LYP/6-311++G(d,p) level of theory with the help of PED compared with the experimental values. The theoretical TD-DFT calculations of UV-vis spectrum show the absorption band (413 $\mathrm{nm}$ ) in chloroform solvent corresponding to $\mathrm{H} \rightarrow \mathrm{L}+2$ (97\%). NLO parameter confirms the optical activity of the DNP compound with a high value of first-order hyperpolarizability that is approximately 110 times greater than the magnitude of urea. The topological analysis based on the Atoms in Molecules theory suggest that the nature of the hydrogen bonds present in the studied compound 
is moderate due to $\nabla^{2}\left(r_{B C P}\right)>0$ and $G\left(r_{B C P}\right)+V\left(r_{B C P}\right)<0$. Finally, the frontier molecular orbital results showed the highly polarizable and chemically reactive. Therefore, this investigated compound shown good interaction with the sites of $3 \mathrm{CL}^{\text {pro }}$ may be considered as a potent inhibitor for COVID-19.

\section{Declarations}

Funding Not applicable

*Availability of data and material Not applicable

Code availability Gaussian 09 Rev. A 11.4 package program, VEDA4 program, Multiwfn software

Authors' contributions The manuscript was written by a single author, who has given approval to the final version of the manuscript. The author would like to thank Prof. Dr. S Sagdinc for the technical support.

Conflict of interest The author declares that he has no competing interest.

\section{References}

[1] Koşar B, Albayrak Ç, Odabaşoğlu M, Büyükgüngör O (2005)2-Hydroxy-6-[(2-hydroxyphenylamino) methylene] cyclohexa-2, 4dienone. Acta Crystallogr E 61:01097-01099

[2] Sun Y, Liu Z, Song R, Yu C, Hao Q, Xu L (2013) Synthesis, structure, vibrational spectral, nonlinear optical and electronbehavioral studies of N-(5-chloro-2- hydroxyphenyl)-(3-hydroxyphenyl)-methalimine. Opt Mater 35(12):2519-2526

[3] Jayabharathi J, Thanikachalam V, Venkatesh Perumal M (2012) Photophysical studies of fused phenanthrimidazole derivatives as versatile-conjugated systems for potential NLO applications. Spectrochim Acta A 92:113-121

[4] Thanthiriwatte KS, Nalin de Silva KM (2002) Non-linear optical properties of novel fluorenyl derivatives-abinitio quantum chemical calculations. J Mol Struct (Theochem) 617:169-175

[5] Sajan D, Hubert J, Jayakumar VS, Zaleski J Structural and electronic contributions to hyperpolarizabilityin methyl p-hydroxy benzoate. J Mol Struct 785:43-53

[6] Karthikeyan MS, Prasad DJ, Poojary B, Subrahmanya Bhat K, Holla BS, Kumari NS (2006) Synthesis and biological activity of Schiff and Mannich bases bearing 2,4-dichloro-5-fluorophenyl moiety. Bioorg Med Chem 14:7482-7489

[7] Al-Omar MA, Amr A El-GE (2010) Synthesis of some new pyridine-2,6-carboxamide-derived Schiff bases as potential antimicrobial agents. Molecules 15:4711-4721

[8] Ünver Y, Deniz S, Çelik F, Akar Z, Küçük M, Sancak K (2016) Synthesis of new 1,2,4-triazole compounds containing Schiff and Mannich bases (morpholine) with antioxidant and antimicrobial activities. J Enzyme Inhib 31:89-95

[9] Azab ME, Rizk SA, Mahmoud NF (2016) Facile synthesis, characterization, and antimicrobial evaluation of novel heterocycles, schiff bases, and N-nucleosides bearing phthalazine moiety. Chem Pharm Bull 64:439-450

[10] El-Faham A, Soliman SM, Ghabbour HA et al. (2016) Ultrasonic promoted synthesis of novel s-triazine-Schiff base derivatives; molecular structure, spectroscopic studies and their preliminary anti-proliferative activities. J Mol Struct 1125:121-135

[11] Amr A El-GE, Sabrry NM, Abdalla M.M, Abdel-Wahab BF (2009) Synthesis, antiarrhythmic and anticoagulant activities of novel thiazolo derivatives from methyl 2-(thiazol-2-ylcarbamoyl)acetate. Eur J Med Chem 44:725-735

[12] Ragab FA, Abdel Gawad NM, Georgey HH, Said MF (2013) Synthesis of novel 1,3,4-trisubstituted pyrazoles as antiinflammatory and analgesic agents. Eur J Med Chem 63:645-654 
[13] Mohamed SF, Flefel EM, Amr A El-GE, Abd El -Shafy DN (2010) Anti-HSV-1 activity and mechanism of action of some new synthesized substituted pyrimidine, thiopyrimidine and thiazolopyrimidine derivatives. Eur J Med Chem 45:1494-1501

[14] Rodriguez M, Ramos-Ortiz G, Maldonado JL, Herrera-Ambriz VM, Dominguez O, Santillan R, Farfan N, Nakatani K (2011) Structural, thermal and optical characterization of a Schiff base as a new organic material for nonlinear optical crystals and films with reversible noncentrosymmetry. Spectrochim Acta A Mol Biomol Spectrosc 79:1757- 1761

[15] O'Boyle, NM, Tenderholt AL, Langner KM (2008) CCLIB: a library for packageindependent computational chemistry algorithms. J Comput Chem 29:839-845

[16] Frisch MJ, Trucks GW, Schlegel HB, Scuseria GE, Robb MA, Cheeseman JR, Scalmani G, Barone V, Mennucci B, Petersson GA, Nakatsuji H, Caricato M, Li X, Hratchian HP, Izmaylov AF, Bloino J, Zheng G, Sonnenberg JL, Hada M, Ehara M, Toyota K, Fukuda R, Hasegawa J, Ishida M, Nakajima T, Honda Y, Kitao O, Nakai H, Vreven T, Montgomery Jr JA, Peralta JE, Ogliaro F, Bearpark M, Heyd JJ, Brothers E, Kudin KN, Staroverov VN, Kobayashi R, Normand J, Raghavachari K, Rendell A, Burant JC, lyengar SS, Tomasi J, Cossi M, Rega N, Millam JM, Klene M, Knox JE, Cross JB, Bakken V, Adamo C, Jaramillo J, Gomperts R, Stratmann RE, Yazyev O, Austin AJ, Cammi R, Pomelli C, Ochterski JW, Martin RL, Morokuma K, Zakrzewski VG, Voth GA, Salvador P, Dannenberg JJ, Dapprich S, Daniels AD, Farkas O, Foresman JB, Ortiz JV, Cioslowski J, Fox DJ (2009) Gaussian 09, Revision D.01. Gaussian Inc., Wallingford

[17] Becke AD (1993) Density-functional thermochemistry. III. The role of exact Exchange. J Chem Phys98:5648-5652

[18] Lee C, Yang W, Parr RG (1988)Development of the Colle-Salvetti correlation-energy formulainto a functional of the electron density. Phys Rev B 37:785-789

[19] Keith T, Millam J (2009) GaussView, Version 5.0.9, Semichem. Inc., Shawnee Mission KS

[20] Jamroz MH (2004) Vibrational Energy Distribution Analysis. VEDA 4 program, Warasaw, Poland

[21] Lu T, Chen F (2012) Multiwfn: A Multifunctional Wavefunction Analyzer. Journal of Computational Chemistry 33:580-592

[22] Albayrak Ç, Odabaşoğlu M, Büyükgüngör O (2005)2-(3-Methoxysalicylideneamino)-1H-benzimidazole monohydrate. Acta Crystallogr E 61:423-424

[23] Albayrak Ç, Kaştaş G, Odabaşoğlu M, Frank R (2011) Probing the compound (E)-5-(diethylamino)-2-[(4-

methylphenylimino)methyl]phenol mainly from the point of tautomerism in solvent media and the solid state by experimental and computational methods.Spectrochim Acta A Mol Biomol Spectrosc81:72-78

[24] Ebrahimipour SY, Sheikhshoaie I, Crochet A, Khaleghi M, Fromm KM (2014) A new mixed-ligand copper(II) complex of (E)-N囚 (2-hydroxybenzylidene) acetohydrazide: Synthesis, characterization, NLO behavior, DFT calculation and biological activities. J Mol Struct 1072:267-276

[25] Halli MB, Sumathi RB, Kinni M (2012) Synthesis, spectroscopic characterization and biological evaluation studiesof Schiff's base derived from naphthofuran-2-carbohydrazide with8-formyl-7-hydroxy-4-methyl coumarin and its metal complexes.Spectrochim Acta A Mol Biomol Spectrosc99:46-56

[26] Bondi A (1964) van der Waals Volumes and Radii. J Phys Chem 68:441-451

[27] Turner MJ, McKinnon JJ, Wolff SK, Grimwood DJ, Spackman PR, Jayatilaka D, Spackman MA (2017) Crystal, Explorer, 17, University of Western Australia, Nedlands, Western Australia

[28] Tanak H, Ağar AA, Büyükgüngör O (2014) Experimental (XRD, FT-IR and UV-Vis) and theoretical modeling studies of Schiff base (E)-N0-((5-nitrothiophen-2-yl)methylene)-2-phenoxyaniline.Spectrochim Acta A Mol Biomol Spectrosc118:672-682

[29] Tamer Ö, Avcı D, Atalay Y (2014) Quantum chemical characterization of N-(2-hydroxybenzylidene) acetohydrazide (HBAH): A detailed vibrational and NLO analysis.Spectrochim Acta A Mol Biomol Spectrosc117:78-86

Page $8 / 22$ 
[30] Ünver H, Boyacioglu B, Zeyrek CT, Yolal D, Yıldız M, Yıldırım N, Demir N, Kiraz A, Elmali A (2018) Experimental, DFT Calculation, Biological Activity, AnionSensing Application Studies and Crystal Structure of (E)-4-[(pyridin-3-ylimino)methyl]benzene-1,3-diol. J Chem Crystallogr 48:32-46

[31] Dollish FR, Fateley WG, Bentley FF (1974) Characteristic Raman Frequencies of Organic Compounds, Wiley

[32] Ristova M, Pejov L, Žugić M, Šoptrajanov B (1999) Experimental IR, Raman and ab initio molecular orbital study of the 4methylbenzenesulfonate anion. J Mol Struct 482:647-651

[33] Tarı GÖ, Ceylan Ü, Ağar E, Eserci H (2016) Crystal structure, spectroscopic investigations and quantum chemical computational study of 5-(diethylamino)-2-((3-nitrophenylimino) methyl)phenol. J Mol Struct1126:83-93

[34] Baranska H, Labudzinska A, Terpinski J (1987) Laser Raman Spectroscopy: Analytical Applications, PWN Polish Scientific Pub

[35] Wojtkowaik B, Chabanel M (1977) Spectrochimie Moleculaire Technique et Documentation, Paris

[36] Pavia DL, Lampman GM, Kriz GS, Vyvyan JR (2009) Introduction to Spectroscopy:A Guide for Students of Organic Chemistry, Brooks/Cole Cengage Learning, USA

[37] Ağar AA, Tanak H, Yavuz M (2010)Experimental and quantum chemical calculational studies on 2-[(4-

propylphenylimino)methyl]-4- nitrophenol. Mol Phys 108:1759-1772

[38] Muthu S, Isac Paulraj E (2012) Molecular structure, vibrational spectra, first order hyper polarizability, NBO and HOMO-LUMO analysis of 4-amino-3(4-chlorophenyl) butanoic acid. Solid State Sci 14:476-487

[39] Bellamy LJ (1975) The Infrared Spectra of Complex Molecules, third ed., Wiley, New York

[40] Tanak H (2011) Crystal structure, spectroscopy, and quantum chemical studies of (E)-2-[(2-Chlorophenyl) iminomethyl]-4trifluoromethoxyphenol. J PhysChem A 115:13865-13876

[41] Jacob George A, Prasana JC, Muthu S, Kuruvilla TK, Sevanthi S, Saji RS (2018) Spectroscopic (FT-IR, FT Raman) and quantum mechanical study on N-(2,6-dimethylphenyl)-2-\{4-[2-hydroxy-3-(2-methoxy phenoxy) propyl]piperazin-1-yl\}acetamide. J Mol Struct $1171: 268-278$

[42] Scrocco E, Tomasi J (1978) Electronic molecular structure, reactivity and intermolecular forces: an euristic interpretation by means of electrostatic molecular potentials. Adv Quant Chem 103:115-193

[43] Tao Y, Han L, Han Y, Liu Z (2015) A combined experimental and theoretical analysis on molecular structure and vibrational spectra of 2, 4-dihydroxybenzoic acid.Spectrochim Acta A Mol Biomol Spectrosc137:1078-1085

[44] Cheeseman JR, Carroll MT, Bader RFW (1998) The mechanics of hydrogen bond formation in conjugated systems. Chem Phys Lett 143:450-548

[45] Rozas I, Alkorta I, Elguero J (2000) Behavior of Ylides Containing N, O, and C Atoms as Hydrogen Bond Acceptors. J Am Chem Soc 122:11154-11161

[46] Parr R, Ayers P, Nalewajski R (2005) What is an atom in a molecule? J Phys Chem A 109:3957-3959

[47] Johnson ER, Keinan S, Sanchez PM, Garcia JC, Cohen AJ, Yang W (2010) Revealing Noncovalent Interactions. J Am Chem Soc 132:6498-6506

[48] Ceylan Ü, Durgun M, Türkmen H, Yalçın ŞP, Kilic A, Özdemir N (2015)Theoretical and experimental investigation of 4-[(2hydroxy-3- methylbenzylidene)amino]benzenesulfonamide: Structural and spectroscopic properties, NBO, NLO and NPA analysis.J Mol Struct1089:222-232 
[49] Lu H, Stratton CW, Tang YW (2020) Outbreak of pneumonia of unknown etiology in Wuhan China: The mystery and the miracle. J Med Virol 92(4):401-402

[50] Morris GM, Huey R, Lindstrom W, Sanner MF, Belew RK, Goodsell DS, Olson AJ (2009) AutoDock4 and AutoDockTools4: automated docking with selective receptor flexibility. J Comput Chem 30:2785-2791

[51] Discovery Studio 4.5 Guide, Accelrys Inc., San Diego, 2009. http://www. accelrys.com.

[52] The PyMOL Molecular Graphics System, Version 1.5.0.4 Schrodinger LLC.

\section{Tables}

Table 1 Experimental and theoretical selected bond lengths, bond angles and dihedral angles with DFT/B3LYP/6-311++G(d,p) level of theory for DNP

Theoretical calculations

Theoretical calculations

\begin{tabular}{|c|c|c|c|c|c|}
\hline Bond & \multicolumn{2}{|l|}{ X-Ray ${ }^{a}$} & Bond Angles $\left(^{\circ}\right)$ & \multicolumn{2}{|l|}{ X-Ray ${ }^{a}$} \\
\hline \multicolumn{6}{|c|}{ Lengths $(\AA ̊)$} \\
\hline 01-C1 & $1.346(3)$ & 1.3417 & $\mathrm{C} 7-\mathrm{N} 2-\mathrm{C} 8$ & 118.8(3) & 120.99 \\
\hline O2-N3 & $1.237(4)$ & 1.2241 & C3-N1-C14 & 120.7(3) & 121.45 \\
\hline O3-N3 & $1.229(4)$ & 1.2219 & C3-N1-C16 & 121.3(3) & 121.08 \\
\hline O4-N4 & $1.221(4)$ & 1.2224 & C14-N1-C16 & 116.4(3) & 117.44 \\
\hline O5-N4 & $1.226(5)$ & 1.2228 & $\mathrm{C} 6-\mathrm{C} 7-\mathrm{N} 2$ & 123.3(3) & 123.01 \\
\hline $\mathrm{N} 2-\mathrm{C} 7$ & $1.284(4)$ & 1.3012 & O2-N3-C10 & 118.5(3) & 117.43 \\
\hline $\mathrm{N} 1-\mathrm{C} 3$ & $1.361(4)$ & 1.3732 & O4-N4-C12 & 118.0(3) & 117.41 \\
\hline $\mathrm{N} 1-\mathrm{C} 14$ & $1.471(4)$ & 1.4662 & Dihedral Angles $\left(^{\circ}\right)$ & & \\
\hline $\mathrm{N} 1-\mathrm{C} 16$ & $1.466(4)$ & 1.4666 & C6-C7-N2-C8 & $-178.7(3)$ & 175.94 \\
\hline N2-C8 & $1.413(4)$ & 1.3943 & $\mathrm{~N} 2-\mathrm{C} 7-\mathrm{C} 6-\mathrm{C} 1$ & $-2.3(5)$ & -1.05 \\
\hline N3-C10 & $1.468(4)$ & 1.4855 & C7-C6-C1-01 & $-6.0(5)$ & 0.38 \\
\hline \multirow[t]{2}{*}{$\mathrm{N} 4-\mathrm{C} 12$} & $1.472(5)$ & 1.4857 & C4-C3-N1-C14 & $-9.0(4)$ & -1.39 \\
\hline & & & C2-C3-N1-C16 & $8.3(4)$ & 0.89 \\
\hline
\end{tabular}

a from Ref [14]; $\AA$ : angstrom unit; ${ }^{\text {o: }}$ degree. 
Table 2 Comparison of the observed and calculated vibrational frequencies $\left(\mathrm{cm}^{-1}\right)$ with the $6-311++G(\mathrm{~d}, \mathrm{p})$ basis set

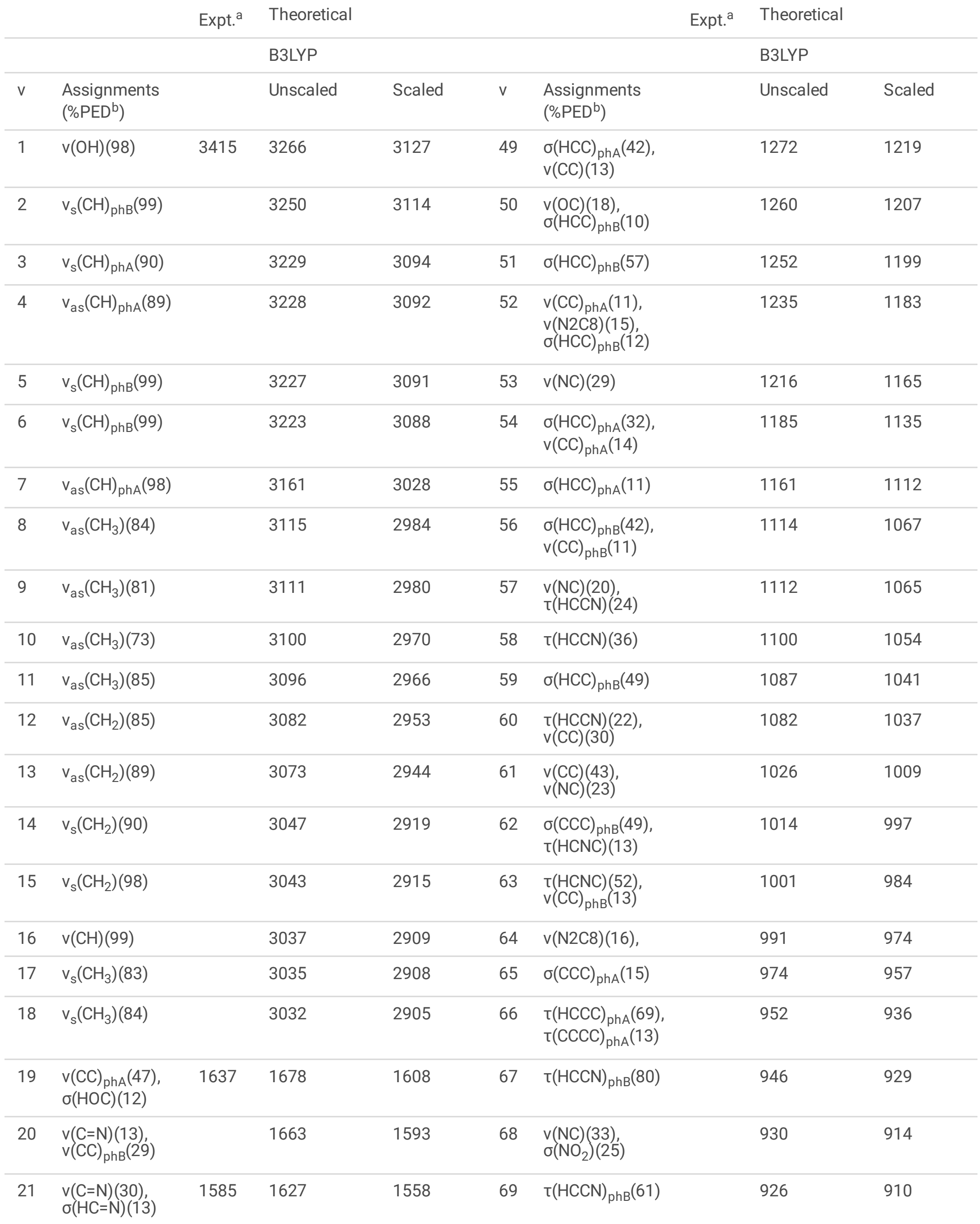




\begin{tabular}{|c|c|c|c|c|c|c|c|c|}
\hline 22 & $\begin{array}{l}\mathrm{v}_{\mathrm{as}}\left(\mathrm{NO}_{2}\right)(21) \\
\mathrm{v}(\mathrm{CC})_{\mathrm{phB}}(26)\end{array}$ & & 1621 & 1553 & 70 & $\tau(\mathrm{HCCN})_{\mathrm{phB}}(56)$ & 921 & 905 \\
\hline 23 & $\mathrm{v}_{\mathrm{as}}\left(\mathrm{NO}_{2}\right)(49)$ & 1532 & 1591 & 1524 & 71 & $\sigma(\mathrm{CCC})_{\mathrm{phA}}(35)$ & 892 & 877 \\
\hline 24 & $\begin{array}{l}\mathrm{v}_{\mathrm{as}}\left(\mathrm{NO}_{2}\right)(47) \\
\mathrm{v}(\mathrm{CC})_{\mathrm{phB}}(11)\end{array}$ & 1512 & 1587 & 1520 & 72 & $\begin{array}{l}\tau(\mathrm{HOCC})(12) \\
\tau(\mathrm{HCCN}))_{\mathrm{phA}}(56)\end{array}$ & 853 & 838 \\
\hline 25 & $\begin{array}{l}\mathrm{v}(\mathrm{CC})_{\mathrm{phA}}(12) \\
\sigma(\mathrm{HOC})(27)\end{array}$ & & 1583 & 1517 & 73 & $\sigma\left(\mathrm{NO}_{2}\right)(32)$ & 844 & 830 \\
\hline 26 & $\begin{array}{l}\sigma(\mathrm{HCC})_{\mathrm{phA}}(22) \\
\mathrm{v}(\mathrm{CC})_{\mathrm{phA}}(25) \\
\mathrm{v}(\mathrm{N} 1 \mathrm{C} 3)(11)\end{array}$ & & 1547 & 1482 & 74 & $\mathrm{\tau}(\mathrm{HOCC})(40)$ & 826 & 812 \\
\hline 27 & $\sigma\left(\mathrm{CH}_{2}\right)(58)$ & & 1528 & 1464 & 75 & $\mathrm{\tau}(\mathrm{HOCC})(34)$ & 822 & 808 \\
\hline 28 & $\sigma\left(\mathrm{CH}_{2}\right)(64)$ & & 1512 & 1448 & 76 & $\tau(\mathrm{HCCC})_{\mathrm{phA}}(61)$ & 796 & 782 \\
\hline 29 & $\sigma\left(\mathrm{CH}_{3}\right)(51)$ & & 1505 & 1442 & 77 & $\begin{array}{l}\text { Y(HCNC)(28), } \\
\text { Y(HCCN)(21) }\end{array}$ & 791 & 778 \\
\hline 30 & $\sigma\left(\mathrm{CH}_{3}\right)(56)$ & & 1498 & 1435 & 78 & $\begin{array}{l}\text { Y(HCNC) }(15) \\
\text { Y(HCCN)(19) }\end{array}$ & 787 & 774 \\
\hline 31 & $\sigma\left(\mathrm{CH}_{3}\right)(55)$ & & 1496 & 1433 & 79 & $\begin{array}{l}\sigma\left(\mathrm{NO}_{2}\right)(31) \\
\sigma(\mathrm{CCC})_{\mathrm{phB}}(25)\end{array}$ & 748 & 735 \\
\hline 32 & $\sigma\left(\mathrm{CH}_{3}\right)(42)$ & & 1490 & 1427 & 80 & $\mathrm{Y}\left(\mathrm{NO}_{2}\right)(74)$ & 745 & 732 \\
\hline 33 & $\sigma\left(\mathrm{CH}_{3}\right)(19)$ & & 1487 & 1425 & 81 & $\begin{array}{l}\mathrm{Y}(\mathrm{OCCC})_{\mathrm{phA}}(16), \\
\mathrm{Y}(\mathrm{NCCC})(14) \\
\mathrm{Y}(\mathrm{CCCC})(11)\end{array}$ & 735 & 723 \\
\hline 34 & $\begin{array}{l}\mathrm{v}(\mathrm{CC})_{\mathrm{phB}}(10) \\
\sigma(\mathrm{HCC})_{\mathrm{phB}}(12)\end{array}$ & & 1482 & 1420 & 82 & $\mathrm{Y}\left(\mathrm{NO}_{2}\right)(57)$ & 725 & 713 \\
\hline 35 & $\begin{array}{l}\sigma(\mathrm{HCC})_{\mathrm{phB}}(21) \\
\mathrm{v}(\mathrm{CC})_{\mathrm{phB}}(48)\end{array}$ & & 1458 & 1397 & 83 & $\sigma(\mathrm{CCC})_{\mathrm{phA}}(23)$ & 717 & 705 \\
\hline 36 & $\begin{array}{l}\mathrm{v}(\mathrm{N} 1 \mathrm{C} 3)(12) \\
\sigma(\mathrm{HOC})(16)\end{array}$ & 1338 & 1453 & 1392 & 84 & $\begin{array}{l}\mathrm{y}(\mathrm{OCCC})_{\mathrm{phA}}(20) \\
\mathrm{y}(\mathrm{NCCC})(29) \\
\mathrm{Y}(\mathrm{HCCC})(17)\end{array}$ & 667 & 656 \\
\hline 37 & $\begin{array}{l}\sigma(\mathrm{HOC})(12), \\
\sigma(\mathrm{HCC})(13)\end{array}$ & & 1423 & 1363 & 85 & $\begin{array}{l}\mathrm{Y}(\mathrm{CCCC})_{\mathrm{phB}}(11) \\
\mathrm{Y}(\mathrm{NCCC})(13)\end{array}$ & 663 & 652 \\
\hline 38 & $\sigma\left(\mathrm{CH}_{3}\right)(58)$ & & 1413 & 1354 & 86 & $\sigma(\mathrm{CCC})_{\mathrm{phB}}(16)$ & 642 & 631 \\
\hline 39 & $\begin{array}{l}v(C=N)(11) \\
\sigma(H C=N)(32)\end{array}$ & & 1399 & 1340 & 87 & $\begin{array}{l}\sigma(\mathrm{ONC})(21), \\
\sigma(\mathrm{NCC})(40)\end{array}$ & 625 & 614 \\
\hline 40 & $\begin{array}{l}\sigma(\mathrm{HCC})(17) \\
\tau(\mathrm{HCNC})(12)\end{array}$ & & 1388 & 1330 & 88 & $\sigma(\mathrm{CCC})_{\mathrm{phA}}(21)$ & 582 & 572 \\
\hline 41 & $\mathrm{v}(\mathrm{CC})_{\mathrm{phA}}(42)$ & & 1382 & 1324 & 89 & $\begin{array}{l}\sigma(\mathrm{CCC})_{\mathrm{phA}}(10) \\
\sigma(\mathrm{CNC})(13)\end{array}$ & 562 & 552 \\
\hline 42 & $\begin{array}{l}\sigma(\mathrm{HCC})(10) \\
\tau(\mathrm{HCNC})(40)\end{array}$ & & 1378 & 1320 & 90 & $\begin{array}{l}\mathrm{\gamma}(\mathrm{CCCC})_{\mathrm{phB}}(14) \\
\mathrm{\gamma}(\mathrm{NCCC})_{\mathrm{phB}}(13)\end{array}$ & 556 & 547 \\
\hline 43 & $\mathrm{v}_{\mathrm{s}}\left(\mathrm{NO}_{2}\right)(65)$ & 1319 & 1375 & 1317 & 91 & $\sigma(\mathrm{ONC})(28)$ & 534 & 525 \\
\hline 44 & $\mathrm{v}_{\mathrm{s}}\left(\mathrm{NO}_{2}\right)(79)$ & 1302 & 1367 & 1310 & 92 & $\begin{array}{l}\sigma(\mathrm{ONC})(29) \\
\sigma(\mathrm{CNC})(17)\end{array}$ & 508 & 499 \\
\hline
\end{tabular}




\begin{tabular}{|c|c|c|c|c|c|c|c|c|}
\hline 45 & $\mathrm{v}(\mathrm{CC})_{\mathrm{phB}}(62)$ & & 1349 & 1292 & 93 & $\begin{array}{l}\sigma(\mathrm{ONC})(11), \\
\sigma(\mathrm{NCC})(10)\end{array}$ & 491 & 483 \\
\hline 46 & $\begin{array}{l}\mathrm{v}(\mathrm{OC})(11) \\
\mathrm{\tau}\left(\mathrm{CH}_{2}\right)(36) \\
\mathrm{Y}(\mathrm{HCNC})(22)\end{array}$ & 1236 & 1340 & 1284 & 94 & $\tau(\mathrm{CCCC})_{\mathrm{phA}}(14)$ & 481 & 473 \\
\hline 47 & $\begin{array}{l}\sigma(\mathrm{HCC})(30) \\
\tau(\mathrm{HCNC})(21)\end{array}$ & & 1318 & 1263 & 95 & $\begin{array}{l}\tau(C C C C)_{\mathrm{phB}}(25) \\
\mathrm{\gamma}(\mathrm{NCCC})_{\mathrm{phB}}(41)\end{array}$ & 472 & 464 \\
\hline \multirow[t]{2}{*}{48} & $\begin{array}{l}v(\mathrm{C} 6 \mathrm{C} 7)(12) \\
\sigma(\mathrm{HC}=\mathrm{N})(18)\end{array}$ & & 1293 & 1239 & 96 & $\sigma(\mathrm{OCC})(32)$ & 449 & 441 \\
\hline & & & & & 97 & $\begin{array}{l}\sigma(C N C)(11), \\
\sigma(C C N)(28)\end{array}$ & 444 & 436 \\
\hline
\end{tabular}

a Taken from Ref.[14]; ${ }^{b}$ Potential Energy Distribution (PED) $\leq 10 \%$ are not shown; $v$, stretching; $\beta$, in-plane bending; $\gamma$, outof-plane bending; $\omega$, wagging; $\tau$, twisting; $\sigma$, scissoring; $\delta$, rocking; s, symmetric; as, asymmetric; ph, phenyl.

\begin{tabular}{|ll|}
\hline \multicolumn{2}{|l|}{ Table 3 Electronic properties of the studied compound } \\
\hline & $\mathrm{B} 3 \mathrm{LYP} / 6-311++\mathrm{G}(\mathrm{d}, \mathrm{p})$ \\
\hline HOMO $(\mathrm{eV})$ & -6.0076 \\
\hline LUMO $(\mathrm{eV})$ & -3.2759 \\
\hline Energy gap $(\mathrm{eV})$ & 2.7317 \\
\hline Ionization potential & 6.0076 \\
\hline Electron affinity & 3.2759 \\
\hline Chemical hardness & 1.3659 \\
\hline Chemical softness & 0.7321 \\
\hline Chemical potential & -4.6418 \\
\hline Electrophilicity index & 0.6830 \\
\hline
\end{tabular}


Table 4 Experimental and calculated absorption wavelength, excitation energies, oscillator strengths and assignments in the acetonitrile solvent using the Time-Dependent DFT/B3LYP/6-311++G(d,p) method
Experimental $^{\mathrm{a}}$
TD-DFT/B3LYP
Major contributions

\begin{tabular}{|c|c|c|c|c|c|}
\hline$\lambda(\mathrm{nm})$ & $E(\mathrm{eV})$ & $\lambda(\mathrm{nm})$ & $f(\mathrm{a} . \mathrm{u})$ & $E(\mathrm{eV})$ & \\
\hline & & 621.01 & 0.0048 & 1.9965 & 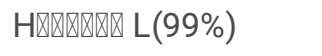 \\
\hline & & 553.23 & 0.0699 & 2.2411 & 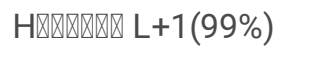 \\
\hline & & 431.08 & 0.0011 & 2.8761 & 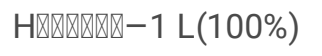 \\
\hline & & 400.32 & 0.0018 & 3.0971 & 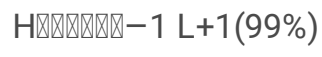 \\
\hline 413 & 3.0024 & 379.34 & 1.2337 & 3.2684 & H \\
\hline & & 357.44 & 0.0342 & 3.4687 & H \\
\hline
\end{tabular}

${ }^{\mathrm{a}}$ Taken from Ref.[14]

Table 6 Dipole moment $\mu$ (D), mean polarizabity $<a>$ (in a.u. and esu), the anisotropic of the polarizability $<\Delta a>$ (in a.u.) and the mean first-order hyperpolarizability $\beta$ (in a.u. and esu) values obtained using B3LYP/6 $-311++G(d, p)$ method

\begin{tabular}{|c|c|c|c|c|c|}
\hline Parameters & B3LYP & Parameters & B3LYP & Parameters & B3LYP \\
\hline$\mu_{x}$ & -11.0226 & $a_{x x}$ & 543.274620 & $\beta_{x x x}$ & 10056.9508749 \\
\hline$\mu_{y}$ & 2.3100 & $a_{x y}$ & -7.646763 & $\beta_{x x y}$ & 163.4117343 \\
\hline$\mu_{z}$ & 1.1285 & $a_{y y}$ & 261.904270 & $\beta_{x y y}$ & 74.0111576 \\
\hline \multirow[t]{10}{*}{$\mu$} & 11.3184 & $a_{x z}$ & 4.581491 & $\beta_{y y y}$ & 195.4884301 \\
\hline & & $a_{y z}$ & 7.332379 & $\beta_{x x z}$ & 313.8828316 \\
\hline & & $a_{z z}$ & 153.741673 & $\beta_{x y z}$ & -244.2255195 \\
\hline & & $<a>$ (a.u.) & 319.6402 & $\beta_{y y z}$ & 5.9875309 \\
\hline & & $<a>x 10^{-24}$ (esu) & 47.3707 & $\beta_{x z z}$ & -200.4013089 \\
\hline & & $<\Delta a>$ (a.u.) & 348.8579 & $\beta_{y z z}$ & 19.0287081 \\
\hline & & $<\Delta a>\times 10^{-24}(\mathrm{esu})$ & 51.7007 & $\beta_{z z z}$ & 33.403582 \\
\hline & & & & $\beta(a . u)$ & 9944.0268 \\
\hline & & & & $\beta_{\text {tot }} \times 10^{-30}$ (esu) & 85.9094 \\
\hline & & & & $\beta_{\text {tot }} / \beta_{\text {urea }}$ & 110 \\
\hline
\end{tabular}


Table 7 Binding Energies, Inhibition constants and Intermolecular energies of the studied Schiff base ligand against the coronavirus main protease

\begin{tabular}{|c|c|c|c|c|c|}
\hline \multirow[t]{2}{*}{ Compound } & $\begin{array}{l}\text { Binding Energy } \\
\text { (kcal/mol) }\end{array}$ & $\begin{array}{l}\text { Inhibition } \\
\text { constant } \\
\text { (M) }\end{array}$ & $\begin{array}{l}\text { Intermolecular } \\
\text { energy } \\
\text { (kcal/mol) }\end{array}$ & $\begin{array}{l}\text { Bond } \\
\text { distances } \\
(\AA)\end{array}$ & $\begin{array}{l}\text { Interaction } \\
\text { Residues }\end{array}$ \\
\hline & 6LU7 & & & & \\
\hline \multirow[t]{3}{*}{ DNP } & -4.68 & 369.18 & -7.07 & 3.3 & PHE3 \\
\hline & & & & 2.1 & ARG4 \\
\hline & & & & 5.6 & LYS5 \\
\hline \multirow[t]{2}{*}{ Favipiravir } & -3.88 & 1.44 & -4.47 & 3.8 & THR11 \\
\hline & & & & 2.2 & ASP295 \\
\hline \multirow[t]{5}{*}{ Remdesivir } & -3.45 & 2.95 & -7.93 & 1.9 & GLU290 \\
\hline & & & & 2.2 & \\
\hline & & & & 2.0 & LYS5 \\
\hline & & & & 2.2 & \\
\hline & & & & 4.2 & TYR126 \\
\hline \multirow[t]{5}{*}{ Chloroquine } & -4.62 & 410.16 & -6.41 & 4.1 & LYS-137 \\
\hline & & & & 5.5 & TYR-126 \\
\hline & & & & 3.6 & ASP-289 \\
\hline & & & & 3.0 & GLU-288 \\
\hline & & & & 3.9 & LYS-5 \\
\hline
\end{tabular}

6LU7; 3-chymotrypsin-like protease

*

Due to technical limitations, Table 5 is only available as a download in the Supplemental Files section.

\section{Figures}

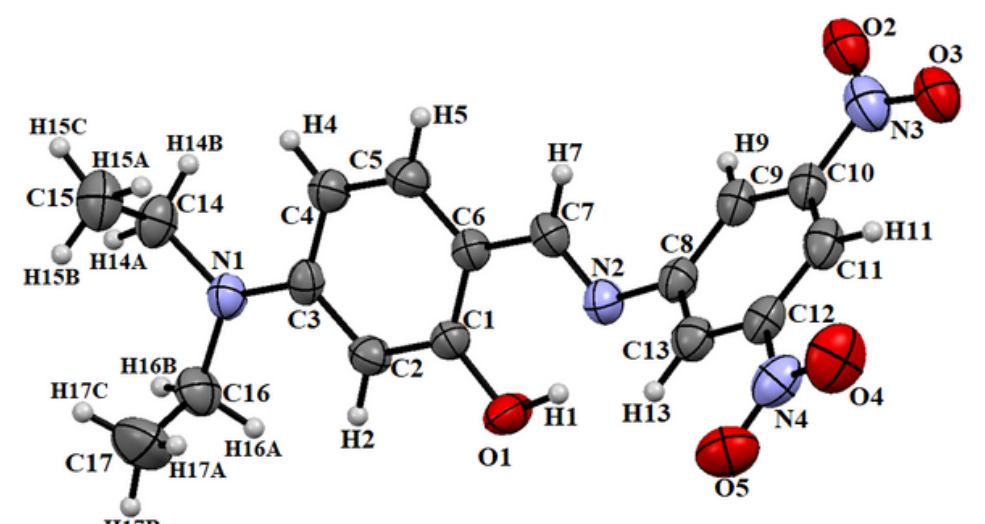

(a)

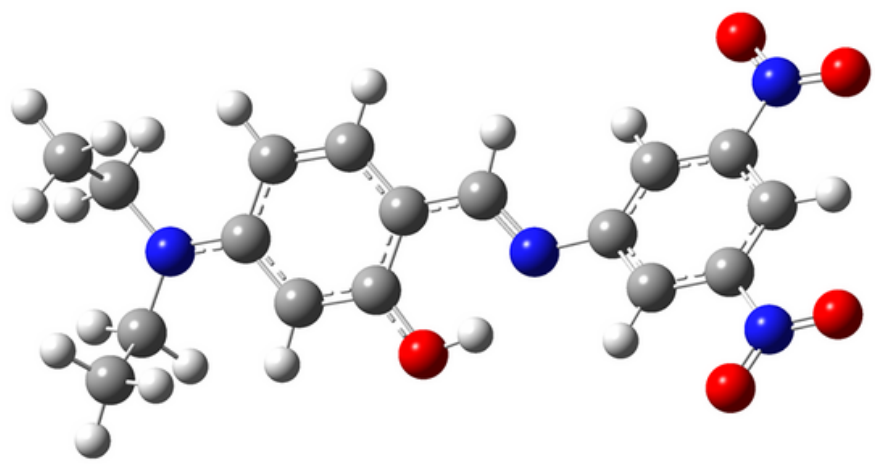

(b)

Figure 1 
(left) the experimental geometry with atom-numbering scheme and (right) the optimize molecular structure obtained at DFT/B3LYP/6-311++G(d,p) level of theory for the (E)-5-(diethylamino)-2-((3,5-dinitrophenylimino)methyl)phenol

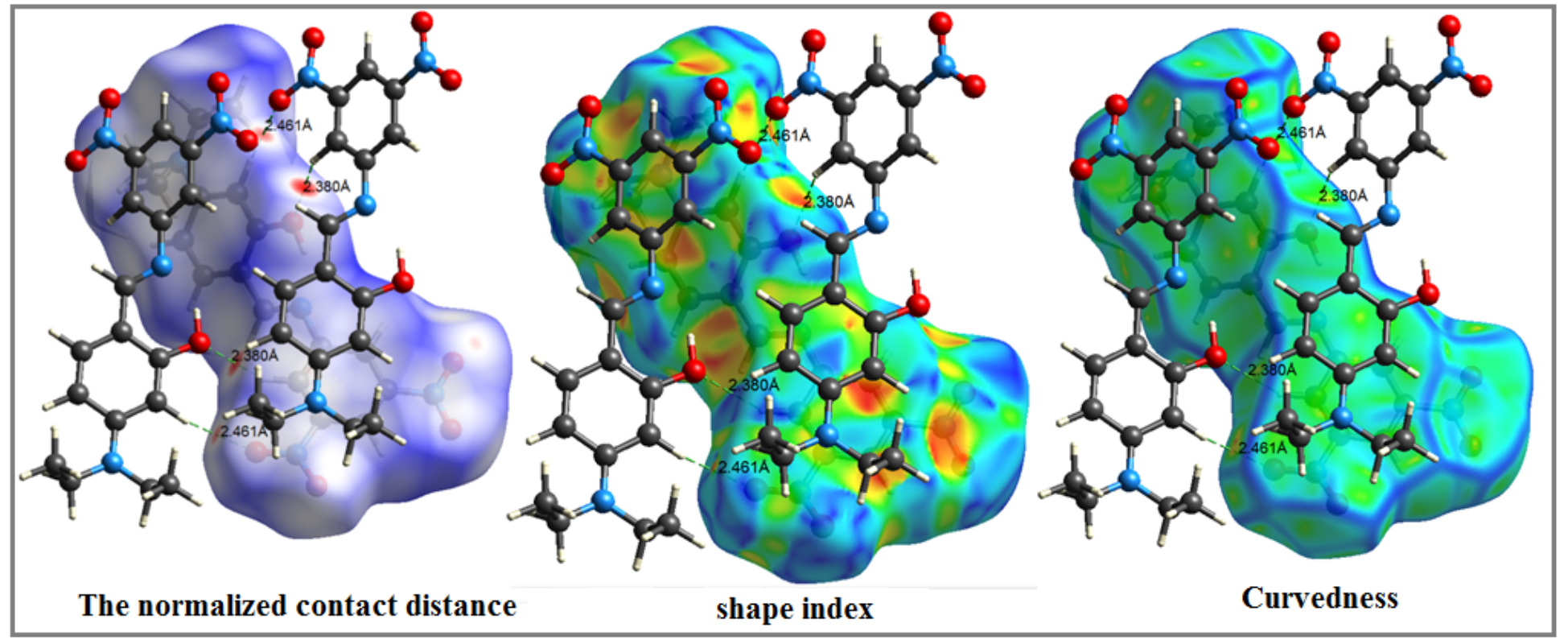

Figure 2

View of the molecular Hirshfeld surfaces: the normalized contact distance, shape index and curvedness of DNP 


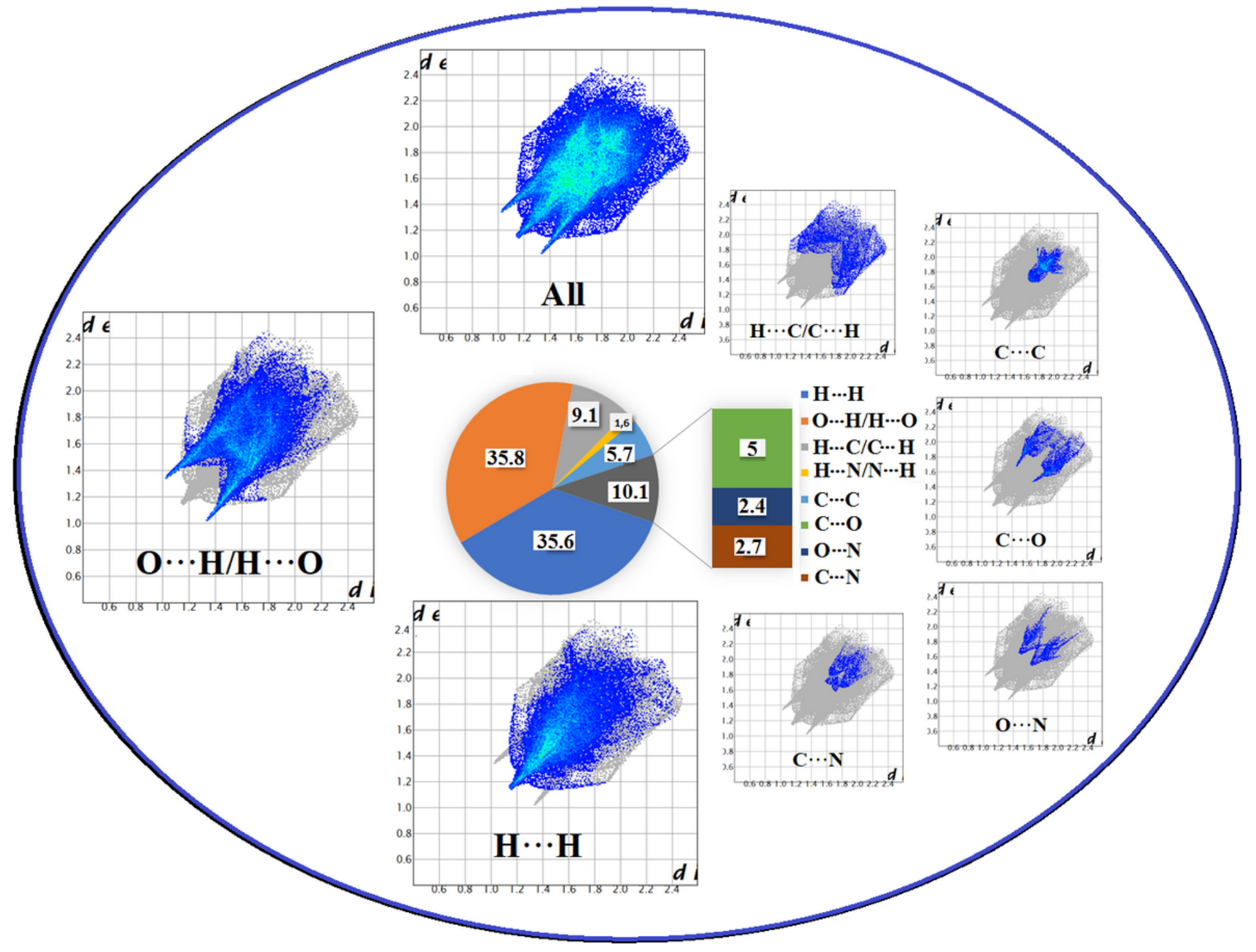

Figure 3

The 2D fingerprint plots represent two di and de distances from the Hirshfeld surface to the nearest internal and external atoms, respectively 


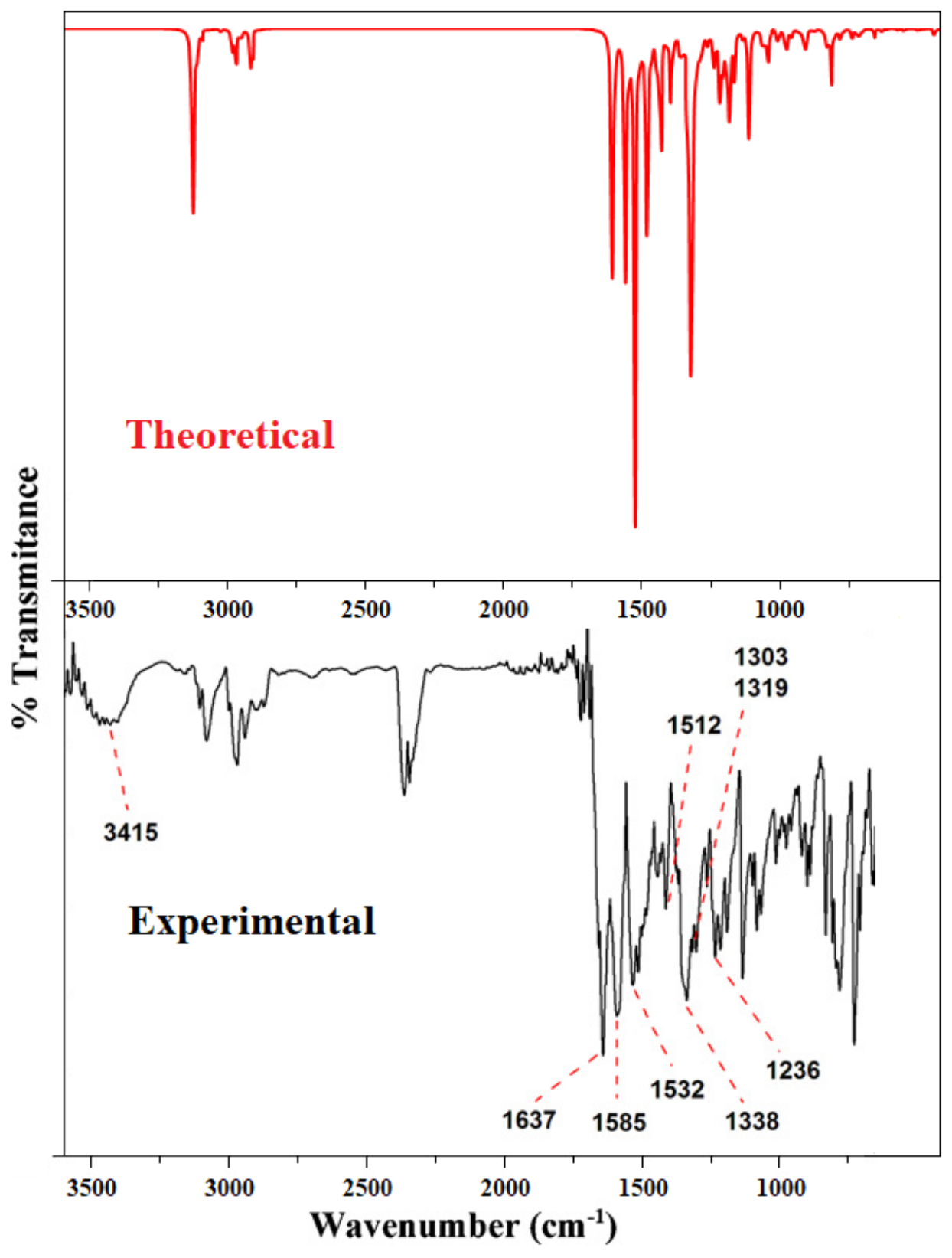

Figure 4

The comparison of experimental and computed FT-IR spectra of DNP 


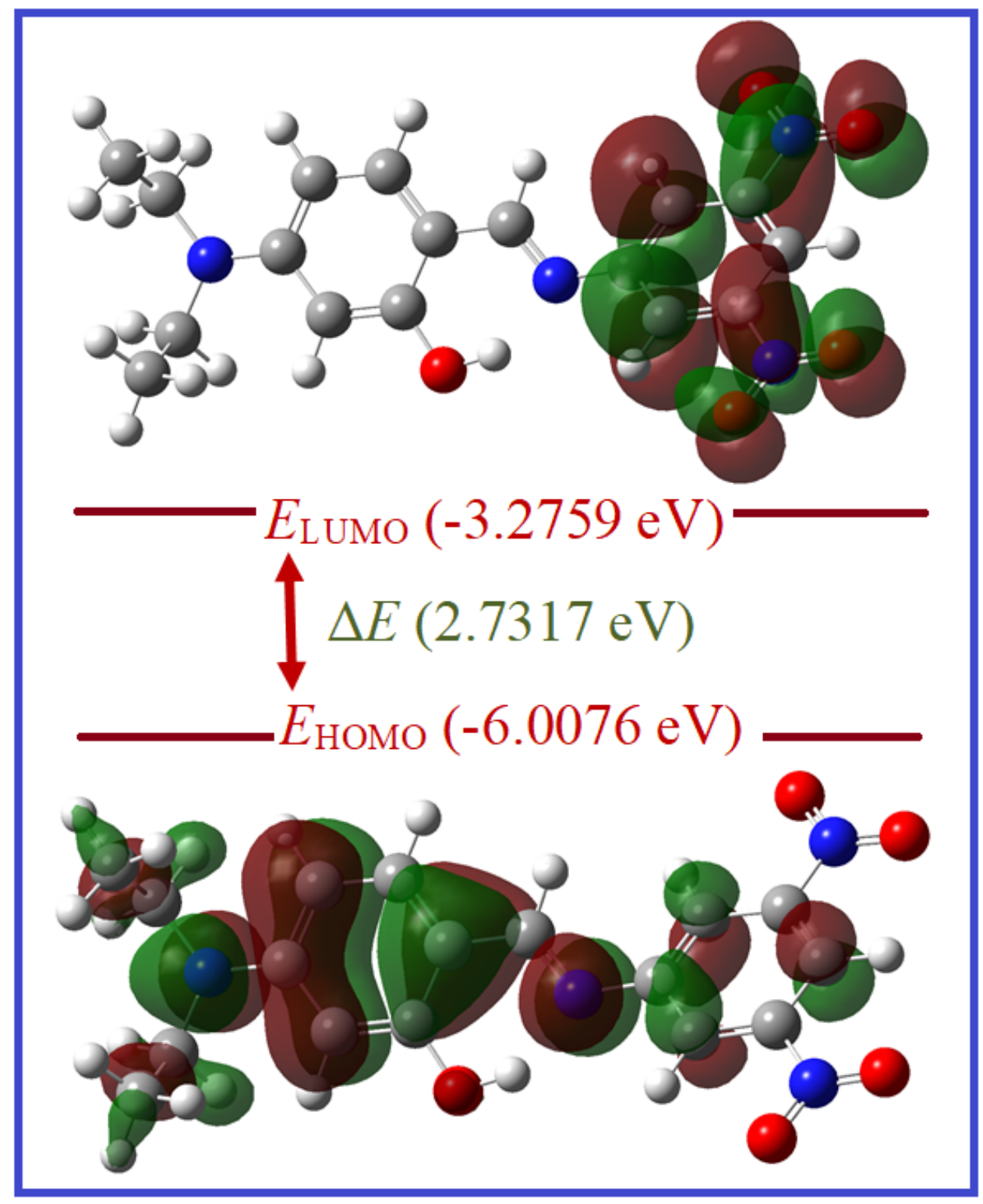

Figure 5

The computed 3D plots of HOMO-LUMO orbitals for the studied compound

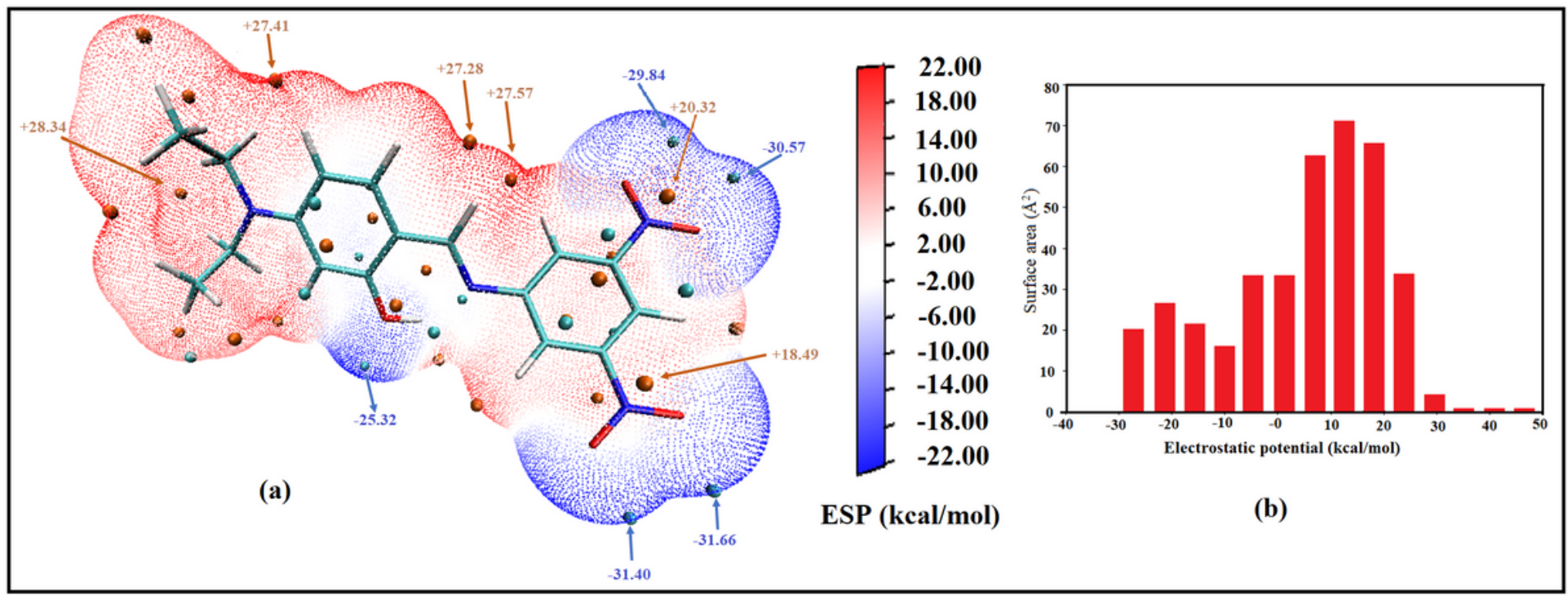


Figure 6

The electrostatic potential mapped on molecular van der Waals surface (a) and area percent in each electrostatic potential range on the van der Waals surface (b) of the studied compound

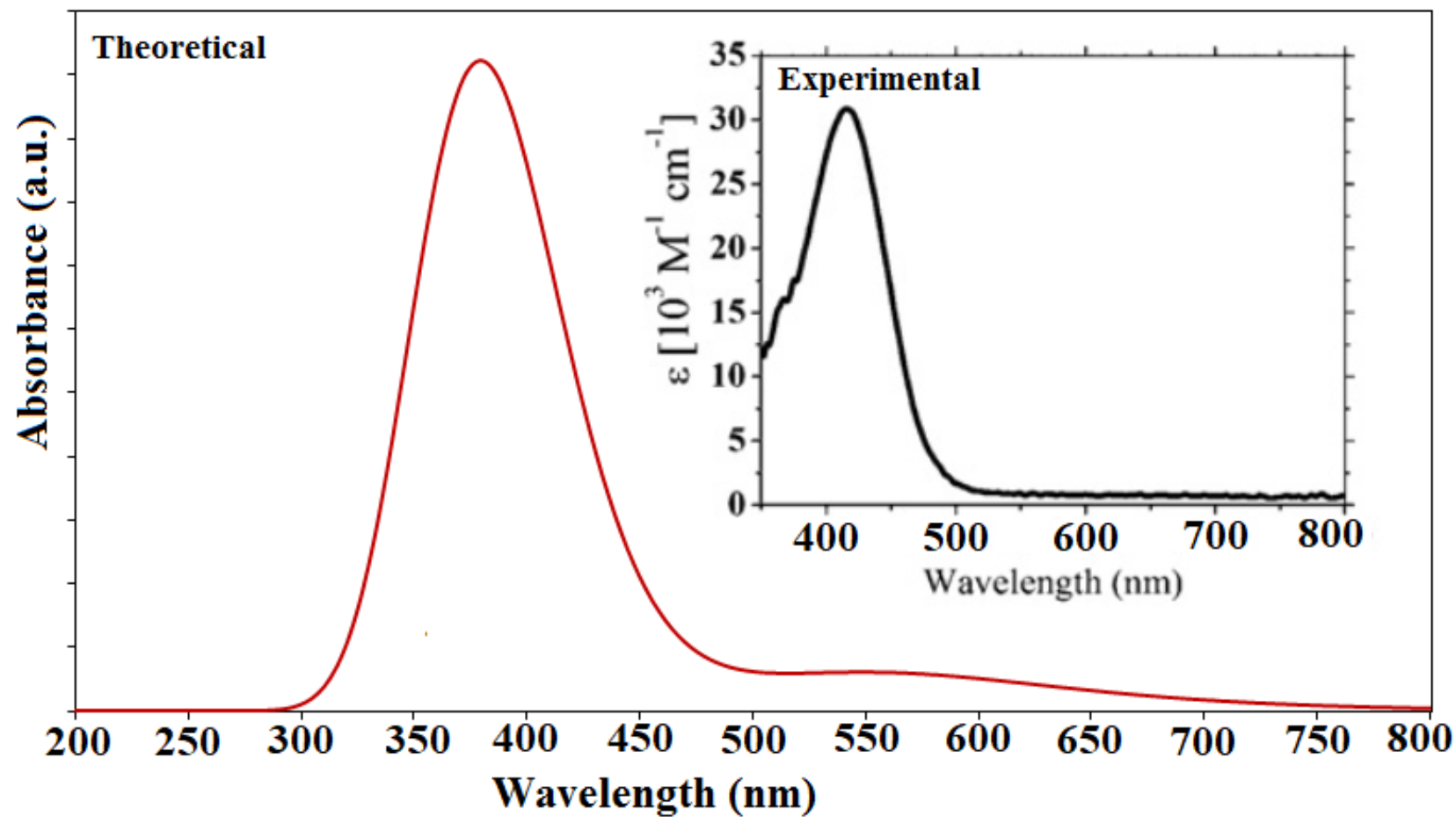

Figure 7

Comparative UV-Vis spectrum using TD-DFT level of theory of DNP in the chloroform solvent

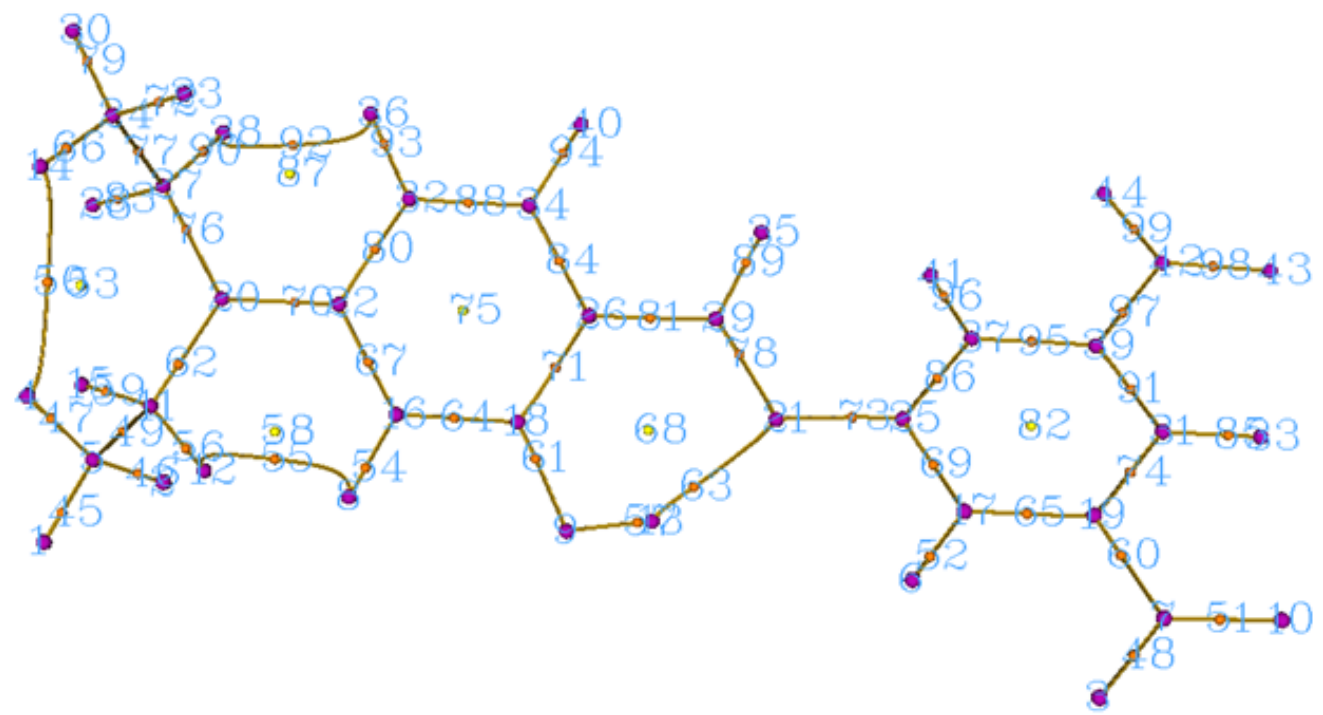

Figure 8

Critical point positions map of the (E)-5-(diethylamino)-2-((3,5-dinitrophenylimino)methyl)phenol 


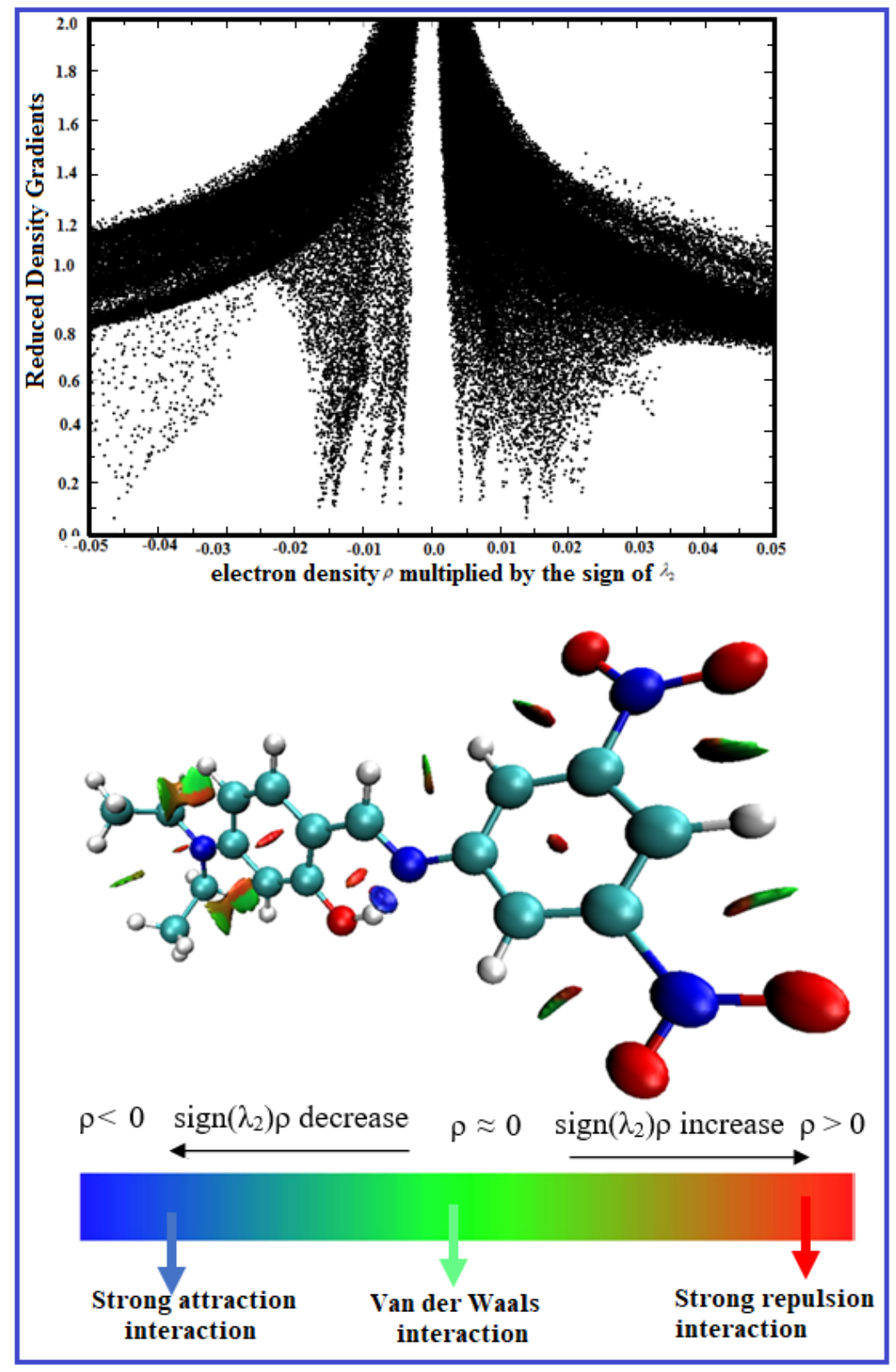

Figure 9

The two-dimensional scatter and coloured isosurface density representations illustrating the non-bonded interactions for DNP 


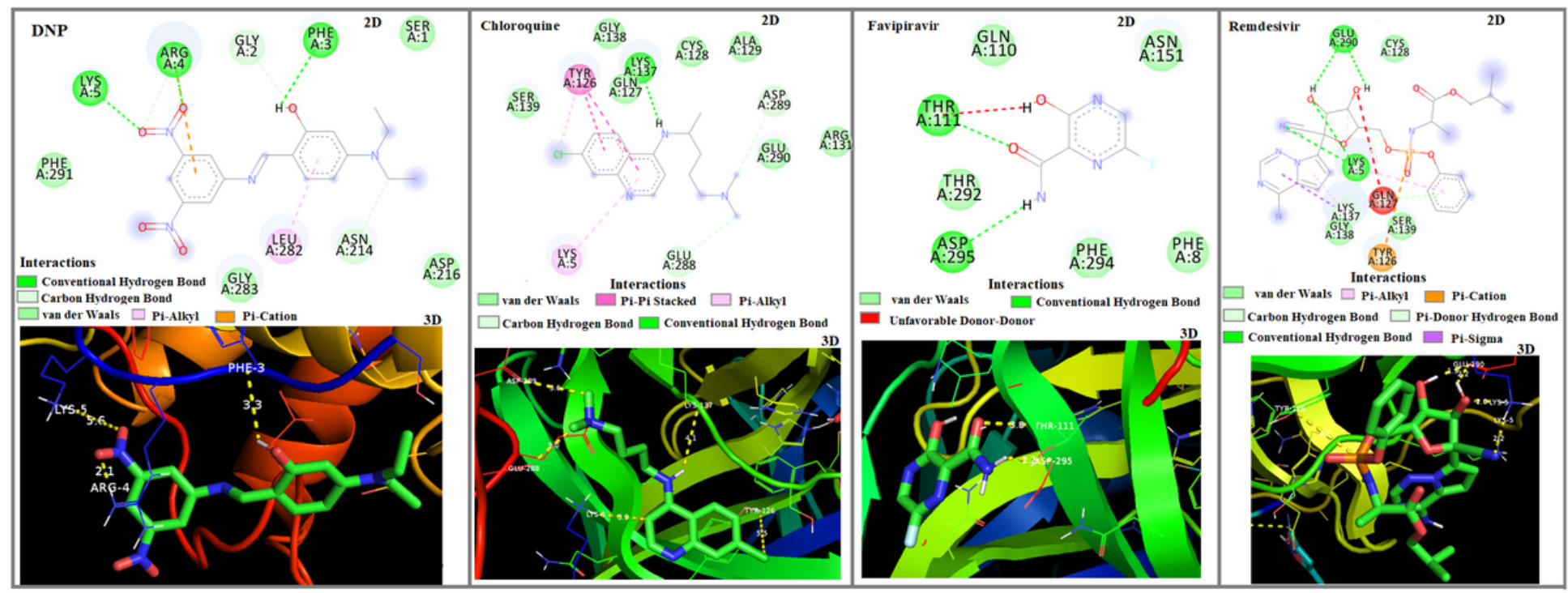

Figure 10

The molecular docking results of DNP compound with the SARS-CoV-2 virus, including a 3-chymotrypsin-like protease.

\section{Supplementary Files}

This is a list of supplementary files associated with this preprint. Click to download.

- asli.esmeTable6.docx 